Article

\title{
Performance Evaluation of Well-Insulated Versions of Contemporary Wall Systems-A Case Study of London for a Warmer Climate
}

\author{
Seyed Masoud Sajjadian
}

Architecture and Design, Southampton Solent University, East Park Terrace, Southampton, SO14 0YN, UK; masoud.sajjadian@solent.ac.uk

Academic Editor: Cinzia Buratti

Received: 19 November 2016; Accepted: 4 January 2017; Published: 11 January 2017

\begin{abstract}
Climate change and its consequences are of a great concern and the likely increasing temperature would add more dilemmas for the choice of passive design options. The performance of building envelopes is one of the key determinants of energy use and thermal comfort. This research presents an evaluation of commonly used construction systems (lightweight and heavyweight) with different levels of thermal mass. The performance of different construction combinations is quantified on the basis of their impact on thermal comfort and energy consumption for current and future time slices in London, UK where climate change impact is expected to be extreme. A flat model is examined as a case study to model the performance of the construction systems with low, medium and high level of thermal mass. The dynamic thermal simulation software used was DesignBuilder, which employs EnergyPlus as its calculation engine. In essence, this study establishes a new approach for assessing the performance of well-insulated contemporary construction systems on the basis of overall annual thermal comfort hours and energy consumption. Results indicate limited advantage of heavyweight construction systems in a changing climate.
\end{abstract}

Keywords: thermal mass; thermal comfort; climate change; energy consumption

\section{Introduction}

In 2007, the UK government's Department for Communities and Local Government (DCLG) issued "Homes for the future: more affordable, more sustainable" [1], which addressed the issue of the UK's housing supply shortages. The government had set, until recently, an ambitious target of two million new dwellings by 2016 and identified the need for house improvement plans to also achieve zero carbon targets. The plans included promoting "Modern Methods of Construction" (MMC) as well as building standards [1]. Thermal mass and high levels of thermal insulation are expected to play significant roles in dwellings achieving these high performance standards. Thermal mass indicates a material's capacity to absorb, store and release heat. It can help to regulate the indoor temperatures of a building [2]. However, the recent usage of MMC in the UK housing has caused a new debate on the value of thermal mass. A number of studies suggested that well insulated buildings with low level of thermal mass might result in higher uncomfortable room temperatures [3,4].

Bill Dunster Architects and Arup R\&D [5] revealed the importance of alleviating climate change consequences by passive design features to offset the predicted temperature rises. Their study also recognized that thermally lightweight homes could experience some levels of discomfort by creating higher room temperatures. The research emphasized that masonry houses with inherent thermal mass can result in less energy consumption over their lifetime compared to a lightweight timber frame house. In a similar vein, Orme et al. [6] presented a study that clarified that in a lightweight, well-insulated house outdoor air temperatures of $29^{\circ} \mathrm{C}$ may cause overheating to more than $39^{\circ} \mathrm{C}$ inside the building. 
This study considers five construction systems with different thermal mass performances. The aim of the study was to provide an insight into the potential role of thermal mass in the UK in dealing with climate change. All the construction systems investigated met the German Passivhaus standard. Passivhaus is one of the world's fastest growing building energy performance standards. It was developed in Germany in the 1990s [7] and sets very high requirements on building envelope thermal performance (U-Value less than $0.15 \mathrm{~W} / \mathrm{m}^{2} \mathrm{~K}$ and air tightness of 0.6 Air Changes per Hour or $\mathrm{ACH}$ at 50 Pascal) [7].

Gradually, potential changes in the UK climate and, consequently, the impacts on the built environment have become widely recognized [8]. Possibly the most important feature of these changes are the impacts of higher air temperature on building thermal performance. Therefore, future thinking in the early design stages of buildings is vital as a principle of sustainable development. Buildings that can respond to future changes are less likely to become obsolete; therefore, key design decisions need to be "future-proof" against long-term environmental changes.

\section{Climate Change in the UK}

Climate change is a crucial future challenge and underlines a reason for long-term thinking in the design decision-making process. Therefore, it is important to address the possible impacts of climate change on the new buildings. Figure 1 shows likely changes in mean annual temperature in the UK by 2080 with different scenarios.

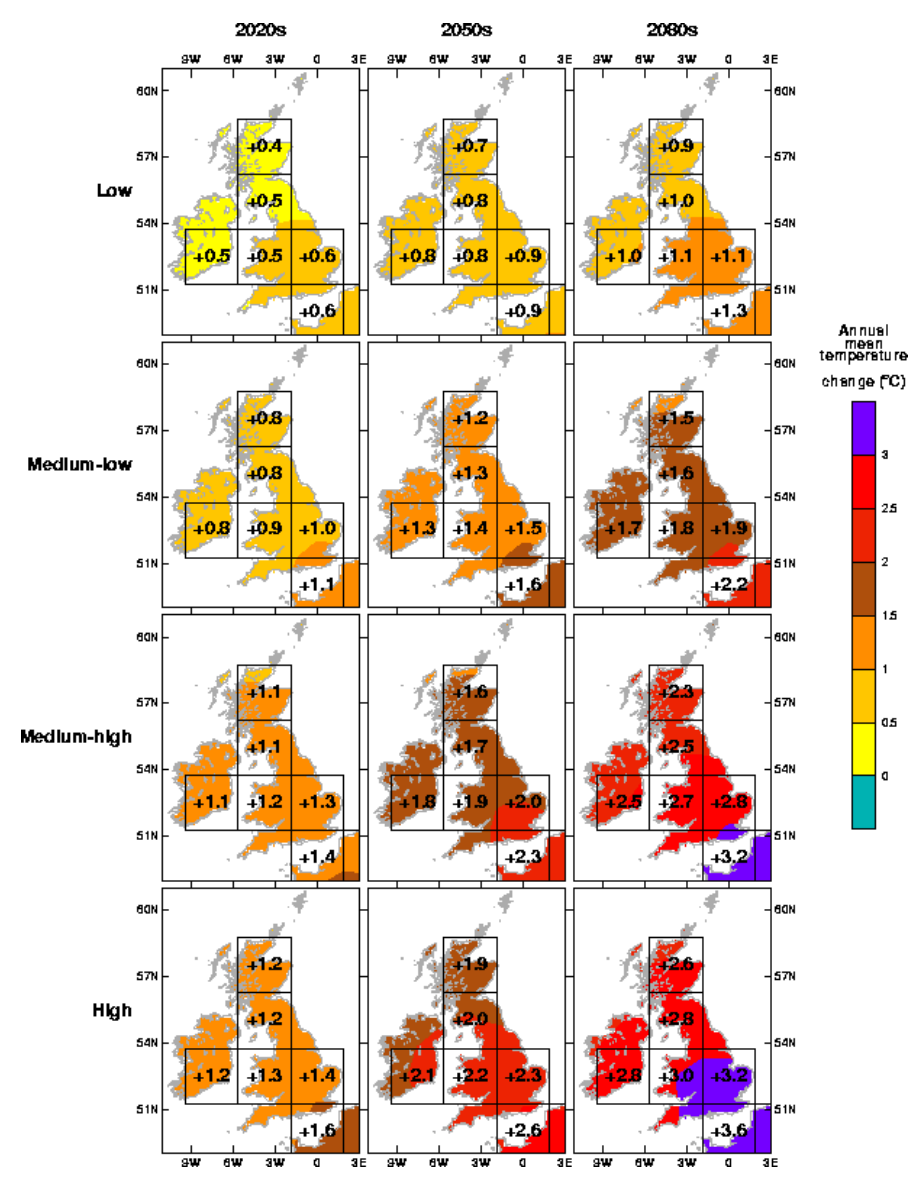

Figure 1. Mean annual temperature increase in 2020, 2050, 2080; $90 \%$ probability level, very unlikely to be less than the degrees shown on maps [9].

Figure 1 highlights that the expected impacts are considerable for many cities in the UK by 2080 even if the low emission scenario take place, and a focus on future building performance should be 
active now. Revealing the likely impacts of climate change will result in optimizing both the energy consumption and thermal comfort of occupants. Currently, a large number of UK dwellings have no mechanical cooling systems [10]. Consequently, temperature increases will, to some extent, increase occupant vulnerability to overheating and clearly more cooling energy will then be required to reduce such vulnerability [11].

\section{Thermal Mass}

In general, thermal mass refers to materials that have capacity to absorb, store and release heat. Therefore, thermal conductivity, specific heat capacity and density as well as the heat transfer can help to characterize thermal mass. There are two major aspects that have to be considered in thermal mass: firstly, the heat flux variation will decrease when traveling through the wall. Secondly, mass is capable of causing a delay to the time of maximum and minimum heat flux occurrence through the wall [12].

Consequently, time is a significant factor for consideration in design decision-making processes. It is not favorable to utilize thermal mass if the time lag is too long-for example if it is more than $12 \mathrm{~h}$, heat will still move to the indoor space when there is more heat available. Also, excessive thermal mass thickness can be unfavorable in cold seasons, as the space will take longer to warm up. Studies by Orme and Palmer in 2003 [13] shows that only $10 \mathrm{~W}$ of excessive heat gain over losses can cause a $17 \mathrm{~m}^{2}$ room temperature to rise by $17^{\circ} \mathrm{C}$ in ten hours. This indicates the importance of the whole building energy balance consideration.

An effective way of optimizing the usage of thermal mass is to maximize the surface of a material rather than its thickness, since this causes heat transfer enhancement between mass and the space. Furthermore, it seems reasonable to provide insulation on the external wall surface to retain the stored heat. Kosny et al. [14] also confirmed lower performance of insulation when installed on the interior side of the building envelope.

CIBSE Guide A [15] gives a comprehensive list of thermal admittance (building fabric response to a swing in temperature), decrement factor (the ability to decrease the amplitude of temperature from outside to inside) and thermal transmittance (also known as U-Value) for a variety of construction systems. This provides valuable insights on thermal properties and their usage in thermal simulations. However, a clarification is needed for the commonly used brick-cavity-block. This is usually considered as a heavyweight construction, but different types of block can have different performances, brick is normally installed behind the insulation and it is the only part to act as the thermal mass in this construction arrangement.

Concrete, brick, concrete block, stone and earth are the most common materials utilized for thermal storage. Materials with dark colors can absorb more solar radiation and therefore are advantageous in this case. Careful consideration should also be given to wall finishes (wallpaper, painting, plasterboards, etc.) as they might hinder the heat transfer between mass and the space [13].

Thermal admittance is a basic factor, which shows the quantity of heat that travels through a material (measured in $\mathrm{W} / \mathrm{m}^{2} \mathrm{~K}$ ). In steady state quantification this is similar to U-Value but it is different when a time factor is considered. Constructions with high thermal mass materials are likely to have a high admittance factor and those with high level of insulations are likely to have lower admittance ratios. Therefore, admittance factor can be a good indicator of thermal mass in construction and can be considered as a dynamic U-Value [16]. The Concrete Centre [17] has also suggested using admittance as a factor to measure thermal mass.

\section{Quantification Framework and Dynamic Thermal Modeling}

Fourier's law of heat conduction states that the rate of heat flow can be obtained from the equation below (where $\mathrm{q}=$ heat flux, $\mathrm{W} / \mathrm{m}^{2}, \mathrm{k}=$ conductivity, $\mathrm{W} / \mathrm{m} \cdot{ }^{\circ} \mathrm{C}$, and $\Delta \mathrm{T} / \Delta \mathrm{x}=$ Temperature gradient, $\left.{ }^{\circ} \mathrm{C} / \mathrm{m}\right)$ :

$$
q=-k \frac{\Delta T}{\Delta x}
$$


By applying this equation to the buildings wall, where $\mathrm{L}$ is the thickness of the wall and heat flows from higher temperature (T1) to the lower (T2) then equation below can be obtained:

$$
\mathrm{q}=-\mathrm{k} \frac{\mathrm{T} 1-\mathrm{T} 2}{\mathrm{~L}}
$$

Considering resistance of the materials, known as R-Value, which refers to $1 \mathrm{~m}^{2}$ of a sample material with $1 \mathrm{~m}$ thickness where there is a $1{ }^{\circ} \mathrm{C}$ temperature difference between surfaces, if the Equation $R=\frac{1}{\mathrm{~K}}$ is substituted in the above equation, then the conductance of a material (also known as U-Value $\left(\mathrm{W} / \mathrm{m}^{2} \cdot{ }^{\circ} \mathrm{C}\right)$ or thermal transmittance) is determined (see equation below). The U-Value is an important factor in the steady state heat loss and gain calculations for building envelopes [18].

$$
\mathrm{U}=\frac{\mathrm{k}}{\mathrm{L}}=\frac{1}{\mathrm{R}}
$$

By applying these to the first equation (Fourier's law) the following can be obtained [19]:

$$
\mathrm{q}=\frac{\Delta \mathrm{T}}{\mathrm{R} 1+\mathrm{R} 2+\ldots+\mathrm{Rn}}(\text { for multi layered wall })
$$

In general, it can be noticed that two walls with the same R-Value or U-Value will conduct the same quantity of heat in steady state. This is the traditional way of assessing heat loss in buildings, which does not consider dynamic behavior of the materials. As two materials that have the same U-Value can perform differently in different construction designs [19].

The final heat fluxes are estimated to be the same in both steady state and transient heat transfer. But if the steady state method were used to calculate through the building envelope, results would be incorrect. This means that the ultimate steady-state condition will not be reached until a definite quantity of energy is conducted through the building envelope. Therefore, the following equation can be applied, where $Q$ is a quantity of energy to cause a temperature change $(\mathrm{kW}), \mathrm{m}$ is mass of the material $(\mathrm{kg})$, and $\mathrm{V}$ is the volume of it $\left(\mathrm{m}^{3}\right)$ [20].

$$
\begin{gathered}
\mathrm{Q}=\mathrm{mc} \Delta \mathrm{T} \\
\mathrm{m}=\rho\left(\text { density of material }, \mathrm{kg} / \mathrm{m}^{3}\right) \mathrm{V}\left(\text { Volume of material }, \mathrm{m}^{3}\right) \\
\mathrm{V}=\mathrm{A}\left(\text { area of material } \mathrm{m}^{2}\right) \mathrm{L}(\text { Thickness of material, } \mathrm{m}) \\
\mathrm{C}=\text { specific heat capacity }\left(\mathrm{kJ} / \mathrm{kg} \cdot{ }^{\circ} \mathrm{C}\right)
\end{gathered}
$$

Furthermore, thermal diffusivity (D) is a quantity that can be obtained from dividing the ability of material to store energy divided by its ability to conduct heat $\left(\mathrm{D}=\frac{\mathrm{k}}{\rho \mathrm{c}}\right.$ where $\mathrm{D}$ is thermal diffusivity $\left(\mathrm{m}^{2} / \mathrm{s}\right), \mathrm{k}$ is conductivity $\left(\mathrm{W} / \mathrm{m} \cdot{ }^{\circ} \mathrm{C}\right), \rho$ is material density $\left(\mathrm{kg} / \mathrm{m}^{3}\right)$ and $\mathrm{c}$ is material specific heat capacity $\left.\left(\mathrm{kJ} / \mathrm{kg} \cdot{ }^{\circ} \mathrm{C}\right)\right)$. Thermal diffusivity indicates the rate at which the temperature profile travels through the wall core which is a useful value in illustrating thermal mass [19]. Materials with high diffusivity respond faster to any temperature fluctuations compared to those with lower diffusivity. Also, thermal effusivity (which is often referred to as thermal inertia) illustrates the transfer of heat through a material's surface. Higher effusivity rates indicate a material's tendency to absorb heat flux on a surface [21].

Diffusivity and effusivity are useful values to understand a material's thermal mass capacity but they do not do so entirely. The other two factors that are necessary to consider are time lag (the time taken the maximum outside temperature to make its way to a maximum inside temperature) and decrement factor (the ability to decrease the amplitude of temperature from outside to the inside) [21]. For more comprehensive assessment, Brisken and Reque [22] suggested a method on the basis of approximating outdoor temperature pulses into triangular temperature pulses and the overall heat 
flux is ascertained as a result of the response to all pulses. This is called a Response Factor Method (RFM) and is used by most building simulation software [23].

Essentially, the response factor method comprises two divisions that are time-domain and frequency-domain response function methods. Both methods originated from the transient heat transfer case. The time-domain approach analyzes hourly indoor conditions on the basis of hourly weather data information, whereas the frequency-domain response method generates a cyclical system response on the basis of a periodic weather cycles [19].

Several methods exist for the purpose of assessing the dynamic thermal performance of buildings, which is advocated by the UK Chartered Institute of Building Service Engineers (CIBSE), and based on frequency-domain method. This method utilizes a material's time lag, decrement factor and admittance to explain its dynamic response [15].

Thermal admittance is a factor, which shows the quantity of heat that travels through a material (measured in $\mathrm{W} / \mathrm{m}^{2} \cdot \mathrm{K}$ ). In steady state quantification this is similar to U-Value but it is different when a time factor is considered in dynamic thermal simulation. Constructions with high thermal mass materials are likely to have a high admittance factor and those with high level of insulations are likely to have lower admittance ratios [15].

\section{Construction Systems}

Five of the most commonly-used construction systems, including traditional and Modern Methods of Construction (MMC) have been selected and optimized to achieve a U-Value $0.1 \mathrm{of} \mathrm{W} / \mathrm{m}^{2} \cdot \mathrm{K}$. A range of low, medium and high thermal mass/admittance factor constructions, each having a thermal insulation thickness to achieve a U-Value 0.1 of $\mathrm{W} / \mathrm{m}^{2} \cdot \mathrm{K}$, were considered in order to quantify the effect of thermal mass. The constructions examined were:

- Brick and block wall (BB)

Housing data suggests that brick and block is the most used construction technique in Britain (88\% of dwellings in England and 69\% in Scotland). This type of construction has a number of variations but the example in this paper (Figure 2) is the most common one. The thermal performance requirements can be achieved by filling the cavity with insulation to achieve the required U-Value [24].

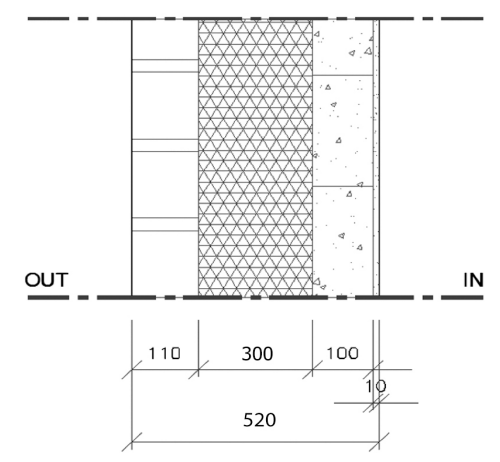

\begin{tabular}{cc}
\hline Decrement factor $(0-1)$ & 0.23 \\
\hline Time Constant $(\mathrm{h})$ & 7.7 \\
\hline Admittance $\left(\mathrm{W} / \mathrm{m}^{2} \cdot \mathrm{K}\right)$ & 5.3 \\
\hline $\mathrm{U}$-Value $\left(\mathrm{W} / \mathrm{m}^{2} \cdot \mathrm{K}\right)$ & 0.1 \\
\hline Thickness $(\mathrm{mm})$ & 520 \\
\hline
\end{tabular}

Figure 2. Brick and block. From out to in: $110 \mathrm{~mm}$ brick outer leaf, $300 \mathrm{~mm}$ phenolic insulation, $100 \mathrm{~mm}$ aerated concrete block, $10 \mathrm{~mm}$ lightweight plaster. 
Timber frame wall (TF)

Timber frame (Figure 3) is the second most commonly used housing construction technique in the UK, used for 7\% and 29\% of residences in England and Scotland, respectively. It is typically composed of factory-made panels and it might receive a range of different cladding. Based on the type and thickness of insulation used, which is usually mineral wool, optimal thermal performance could be achieved [24].

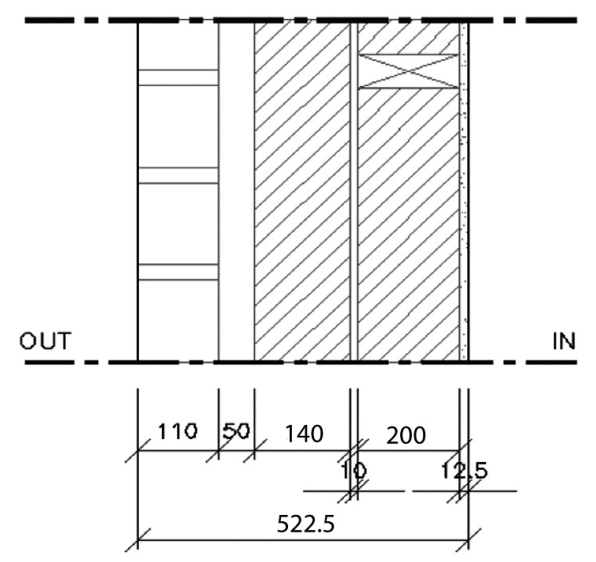

\begin{tabular}{cc}
\hline Decrement factor $(0-1)$ & 0.2 \\
\hline Time Constant $(\mathrm{h})$ & 3 \\
\hline Admittance $\left(\mathrm{W} / \mathrm{m}^{2} \cdot \mathrm{K}\right)$ & 1.54 \\
\hline U-Value $\left(\mathrm{W} / \mathrm{m}^{2} \cdot \mathrm{K}\right)$ & 0.1 \\
\hline Thickness $(\mathrm{mm})$ & 522.5 \\
\hline
\end{tabular}

Figure 3. Timber frame. From out to in: $110 \mathrm{~mm}$ brick outer leaf, $50 \mathrm{~mm}$ air gap, $140 \mathrm{~mm}$ rockwool, $10 \mathrm{~mm}$ plywood, $200 \mathrm{~mm}$ rockwool, $12.5 \mathrm{~mm}$ plasterboard.

- Insulating concrete formwork (ICF)

Insulating concrete formwork (Figure 4) is one of the common modern methods of construction in the UK. Both off-site and on-site assembly methods are possible. The insulation is fixed as part of the structure. The thermal mass of the insulated concrete causes this wall to achieve a high time constant [25] (the time it takes the maximum outside temperature to result in a maximum inside temperature [8]). 


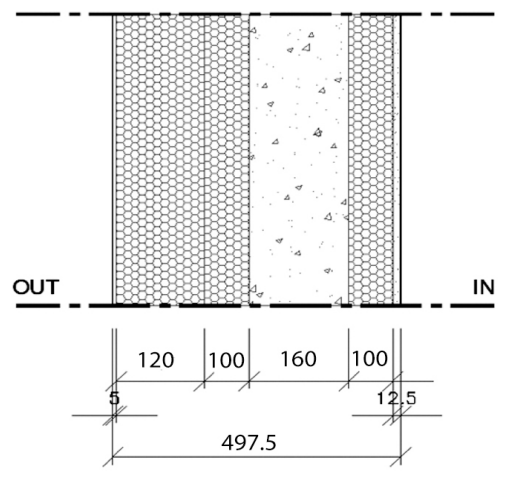

\begin{tabular}{cc}
\hline Decrement factor $(0-1)$ & 0.47 \\
\hline Time Constant $(\mathrm{h})$ & 5 \\
\hline Admittance $\left(\mathrm{W} / \mathrm{m}^{2} \cdot \mathrm{K}\right)$ & 2.96 \\
\hline $\mathrm{U}-$ Value $\left(\mathrm{W} / \mathrm{m}^{2} \cdot \mathrm{K}\right)$ & 0.1 \\
\hline Thickness $(\mathrm{mm})$ & 497.5 \\
\hline
\end{tabular}

Figure 4. Insulated concrete formwork. From out to in: $5 \mathrm{~mm}$ Rendering, $120 \mathrm{~mm}$ extruded polystyrene (EPS), $100 \mathrm{~mm}$ extruded polystyrene (EPS), $160 \mathrm{~mm}$ heavyweight concrete, $100 \mathrm{~mm}$ extruded polystyrene (EPS), $12.5 \mathrm{~mm}$ plasterboard.

- Structural insulated panel (SIPs)

Structural insulated panels (Figure 5) are considered to be one of the common modern methods of construction in the UK. Flexibility in the design because of its lightness and strength cause thermal bridging and infiltration to be minimized effectively, although this might cause the risk of more hours of overheating in the summer time and the advantage of reduced thermal loads in the winter [26].

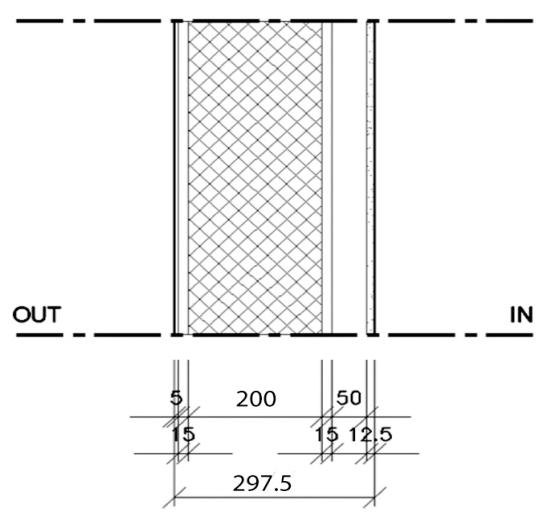

\begin{tabular}{cc}
\hline Decrement factor $(0-1)$ & 0.81 \\
\hline Time Constant $(\mathrm{h})$ & 2.4 \\
\hline Admittance $\left(\mathrm{W} / \mathrm{m}^{2} \cdot \mathrm{K}\right)$ & 1.16 \\
\hline U-Value $\left(\mathrm{W} / \mathrm{m}^{2} \cdot \mathrm{K}\right)$ & 0.1 \\
\hline Thickness $(\mathrm{mm})$ & 297.5
\end{tabular}

Figure 5. Structural insulated panel. From out to in: $5 \mathrm{~mm}$ rendering, $15 \mathrm{~mm}$ softwood board, $200 \mathrm{~mm}$ extruded polyurethane (PUR), $15 \mathrm{~mm}$ softwood board, $50 \mathrm{~mm}$ air gap, $12.5 \mathrm{~mm}$ plasterboard. 
Steel frame wall (SF)

This type of construction technique (Figure 6) is similar to timber-frame, having considerable design flexibility; various cladding options as well as the possibility of prefabrication are the main advantages of it [25].

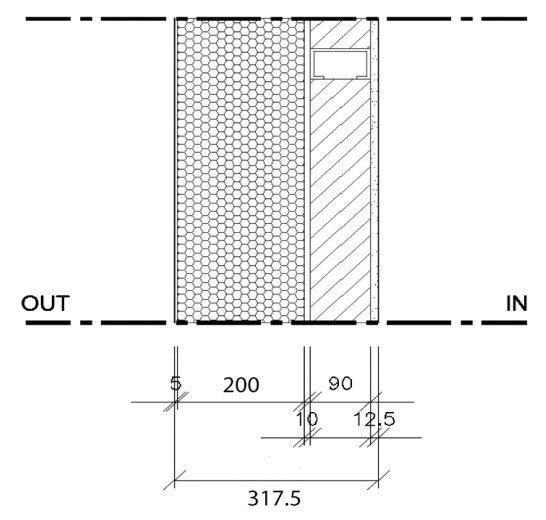

\begin{tabular}{cc}
\hline Decrement factor $(0-1)$ & 0.36 \\
\hline Time Constant $(\mathrm{h})$ & 4.9 \\
\hline Admittance $\left(\mathrm{W} / \mathrm{m}^{2} \cdot \mathrm{K}\right)$ & 1.39 \\
\hline U-Value $\left(\mathrm{W} / \mathrm{m}^{2} \cdot \mathrm{K}\right)$ & 0.1 \\
\hline Thickness $(\mathrm{mm})$ & 317.5 \\
\hline
\end{tabular}

Figure 6. Steel frame. From out to in: $5 \mathrm{~mm}$ rendering, $200 \mathrm{~mm}$ extruded polystyrene (EPS), $10 \mathrm{~mm}$ plywood, $90 \mathrm{~mm}$ rockwool, $12.5 \mathrm{~mm}$ plasterboard.

Figure 7 highlights the major differences between the constructions systems. TF has the lowest decrement factor compared to the others, which implies a lower thermal conductivity. SF and SIP have slightly different properties and BB shows the highest admittance rate, although TF and ICF becomes the thickest wall to achieve a $0.1 \mathrm{U}$-Value.

These construction systems were then examined by dynamic thermal simulation software using current and future UK climate data. Future climate data for the UK are available from the UK Climate Impact Program (UKCIP), which provides monthly values of climate data for the UK until 2080 [27]. The University of Southampton has developed an Excel-based software named "CCWeather Gen" that can create future weather files in the .EPW format, required for DB. These files provide hourly weather data for modeling in this study. Figure 8 demonstrates the likely changes in average dry bulb temperature from 2011 to 2080 as generated from the aforementioned software. The generated future weather file shows from $2{ }^{\circ} \mathrm{C}$ to almost $5{ }^{\circ} \mathrm{C}$ temperature difference from 2011 to 2080 .

In developing appropriate projections for modeling, the "extreme" climate change for three climate periods were used, as they represent the worst-case scenario for climate change. The importance of using worst-case scenario is due to the fact that the model adapted for the worst scenario is highly likely to be the most robust design and the model which is most resilient to the greatest change in future climate. Extreme climate change characterizes the high emissions scenario at $90 \%$ probability (where change is highly unlikely to be more than a given value). 


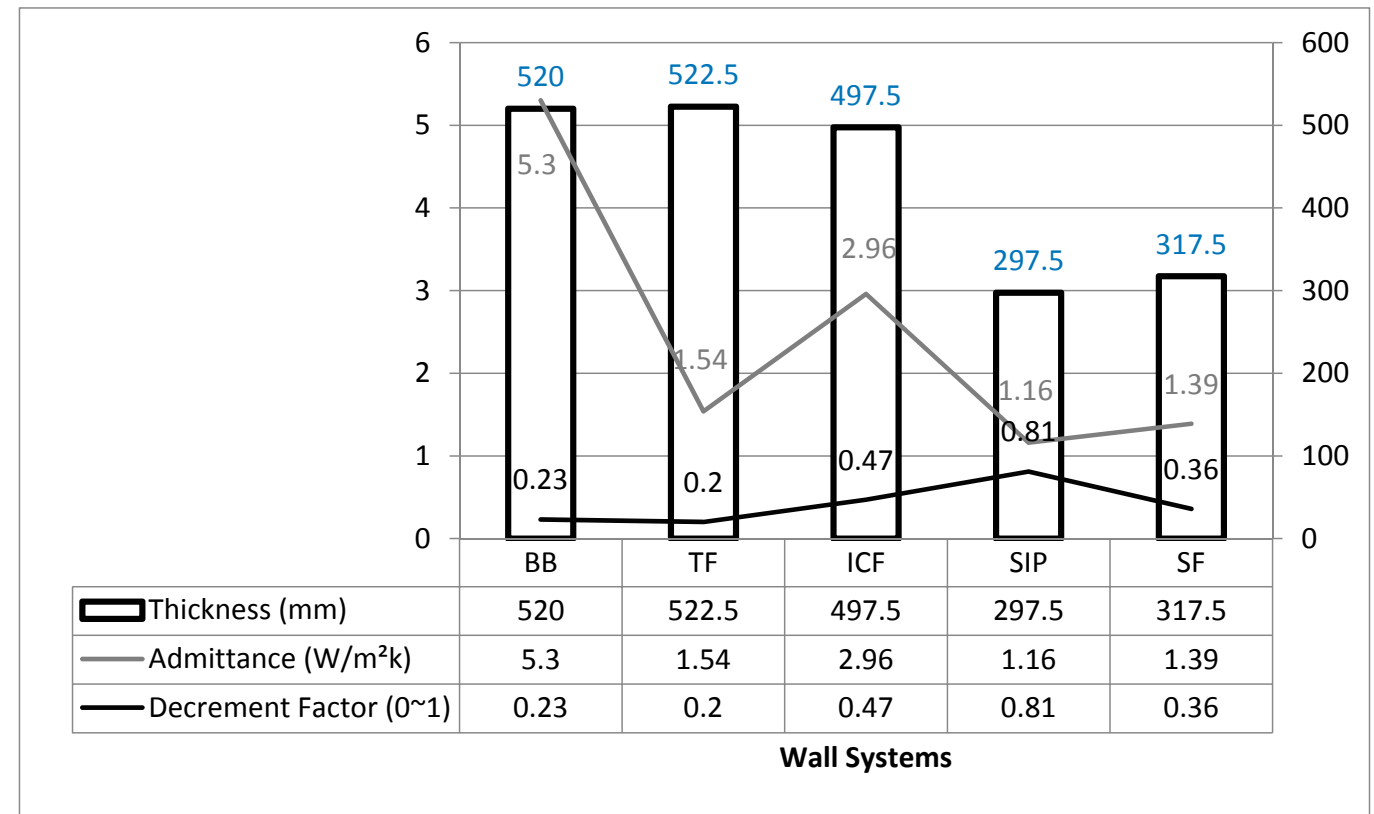

Figure 7. Admittance, decrement factor and thickness of examined walls.

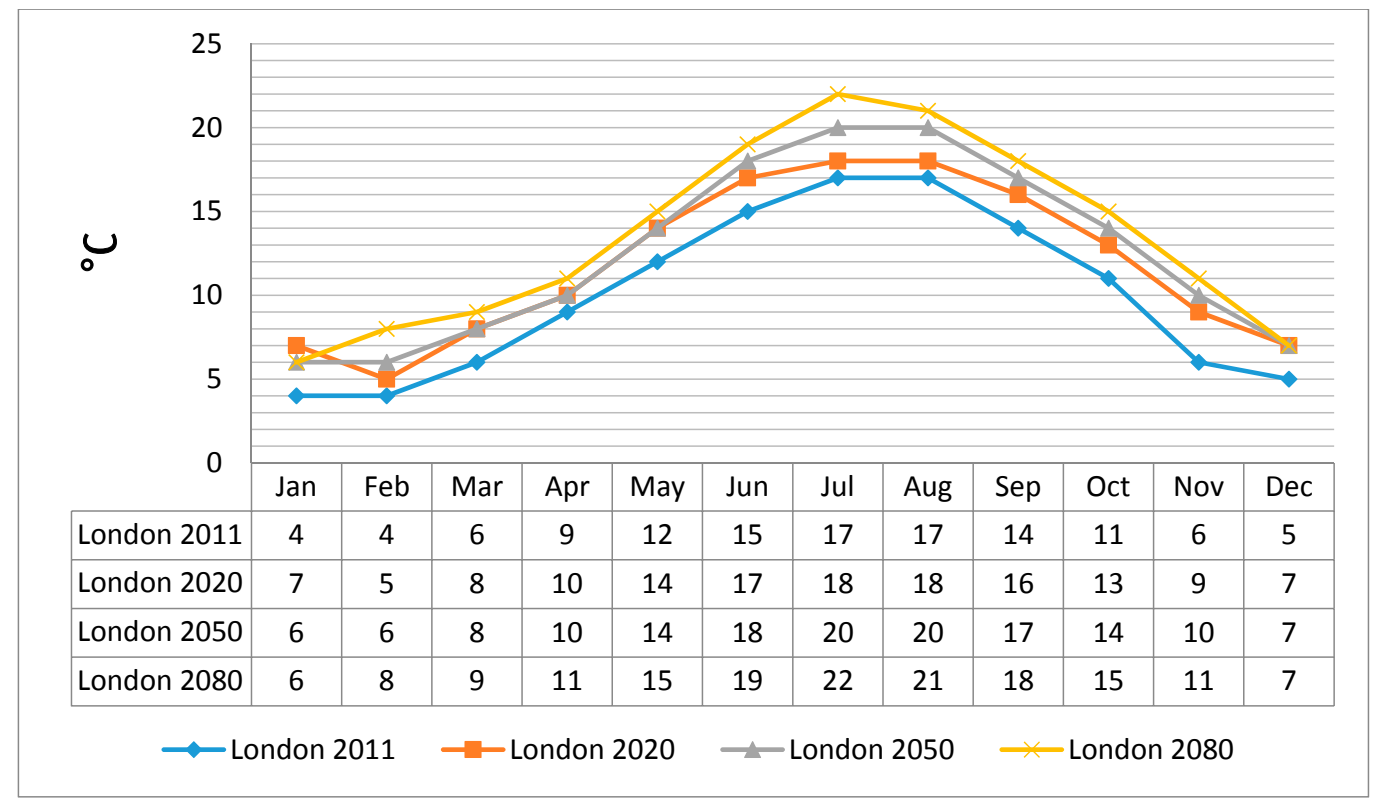

Figure 8. Monthly average dry bulb temperature in 2011, 2020, 2050 and 2080, London.

\section{Thermal Comfort}

A number studies have proposed temperatures range of $18-26^{\circ} \mathrm{C}$ as highly likely to be within the comfort area [28]. Also, ASHRAE 55-2013 refined thermal comfort as a subjective response and defined it as the "state of mind that expresses satisfaction with the existing environment" [20]. Therefore, it seems that a precise value cannot be assigned to thermal comfort. "State of mind" largely depends on a person's perceptions and expectations. However, the ASHRAE-55 suggested the static heat balance approach as a reasonable way to quantify thermal comfort. The standard includes four environmental variables (dry bulb air temperature, mean radiant temperature, relative humidity and air velocity) and two person-based parameters (activity level and clothing level). For simplification and quantification 
purposes, this paper assumes the ASHRAE-55 standard as static heat balance approach to assess comfort results. Figure 8 shows the range of comfort conditions in this standard. Discomfort hours are therefore defined as those that inside model is experiencing temperature above or below comfort zone level as shown in Figure 9 (for all simulations, the clothing level is considered 1 for the period of 1 October to 31 March and 0.5 for the period of 1 April to 30 September).

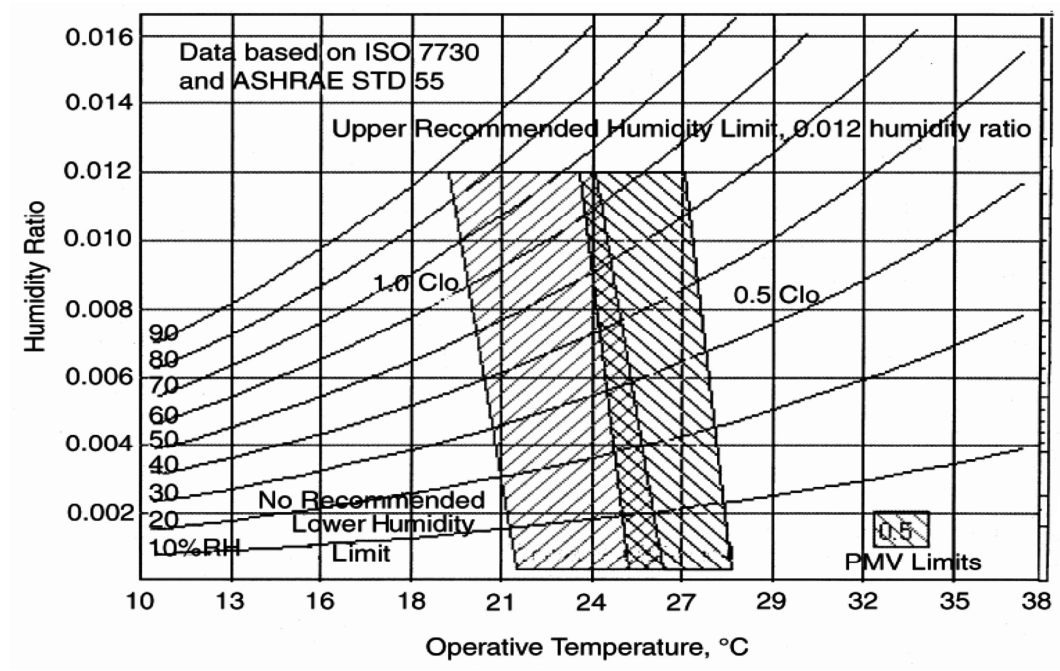

Figure 9. ASHRAE Comfort Zone.

Clothing insulation is expressed in clo-a unit used to express the thermal insulation provided by garments and clothing ensembles-where $1 \mathrm{clo}=0.155 \mathrm{~m}^{2} \cdot{ }^{\circ} \mathrm{C} / \mathrm{W}$.

\section{Case Study}

For the purposes of the study, a four-storey block of flats were designed by the author to near Passivhaus standards for dynamic thermal simulations. The flat on the second floor was used for calculations. Each flat had three bedrooms and a U-Value of $0.1 \mathrm{~W} / \mathrm{m}^{2} \cdot \mathrm{K}$ for the exterior walls, which were constructed with each of the five construction systems described. An infiltration rate of 0.6 air changes per hour was set. Natural ventilation has also been considered and windows were triple glazed (U-Value of $0.8 \mathrm{~W} / \mathrm{m}^{2} \cdot \mathrm{K}$ ). Roofs and ground floor remained the same for all simulations and are shown in Figure 10. Figures 11 and 12 demonstrate plans and elevations used for the simulations respectively.

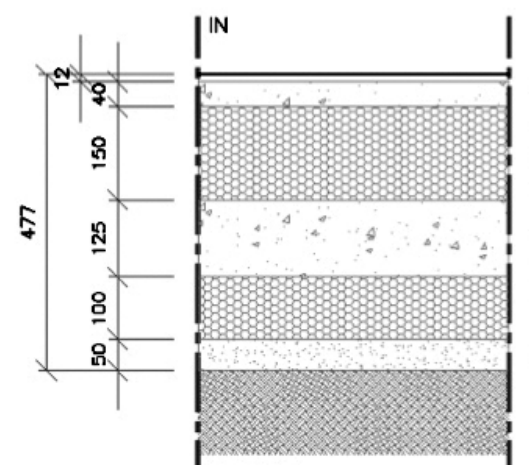

(a)

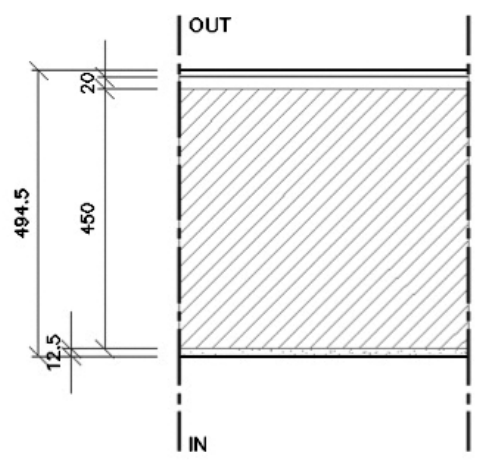

(b)

Figure 10. Ground floor and roof used for simulation in the model. (a) Ground floor. From top to button; $12 \mathrm{~mm}$ pine wood floor, $40 \mathrm{~mm}$ concrete screed, $150 \mathrm{~mm}$ extruded polystyrene (EPS), $125 \mathrm{~mm}$ concrete slab, $100 \mathrm{~mm}$ extruded polystyrene (EPS), $50 \mathrm{~mm}$ sand, crushed brick; (b) Roof. From top to button; clay roof tile, roofing felt, $20 \mathrm{~mm}$ air cavity, $450 \mathrm{~mm}$ rockwool, $12.5 \mathrm{~mm}$ plasterboard. 

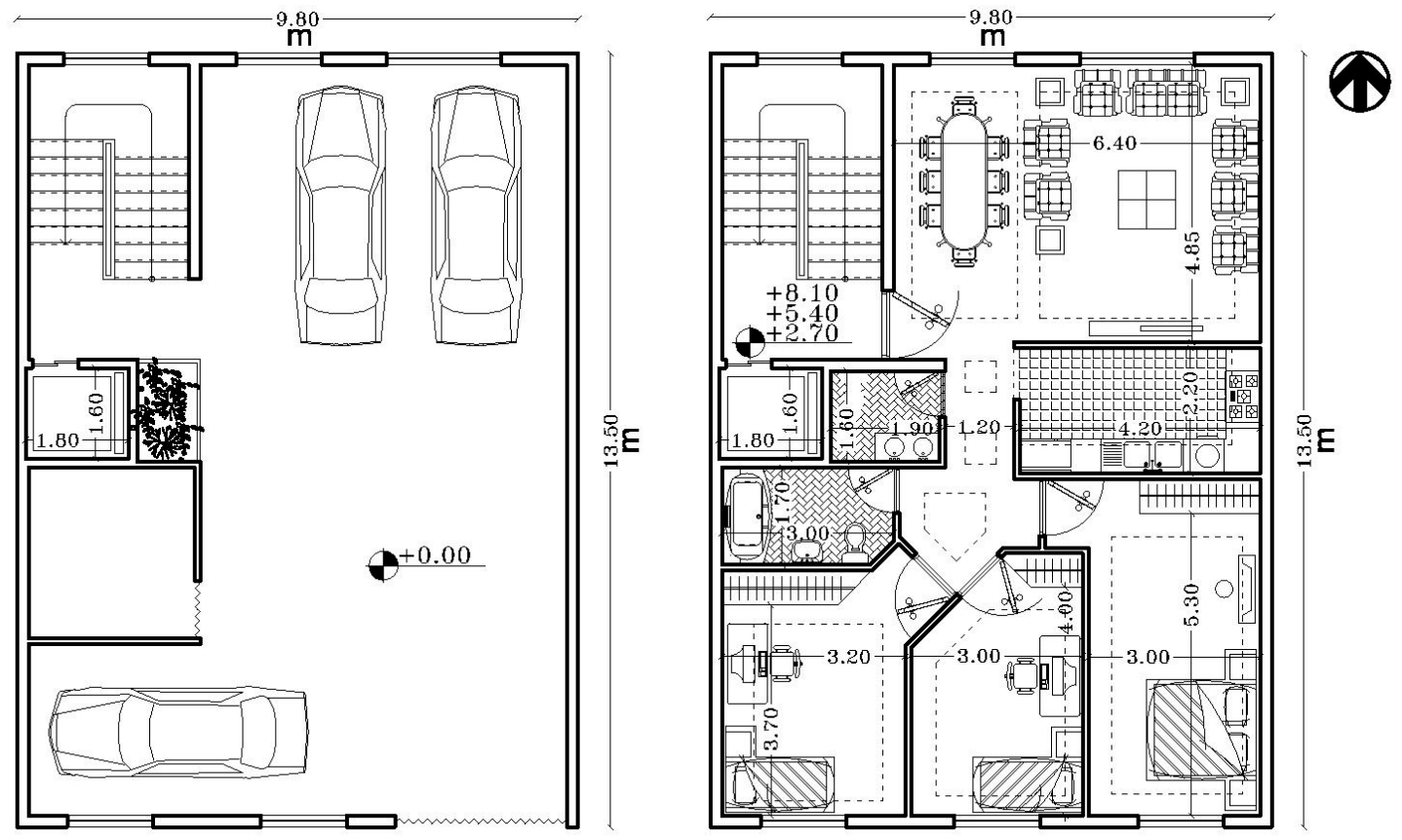

Figure 11. Ground floor and first floor (left to right).
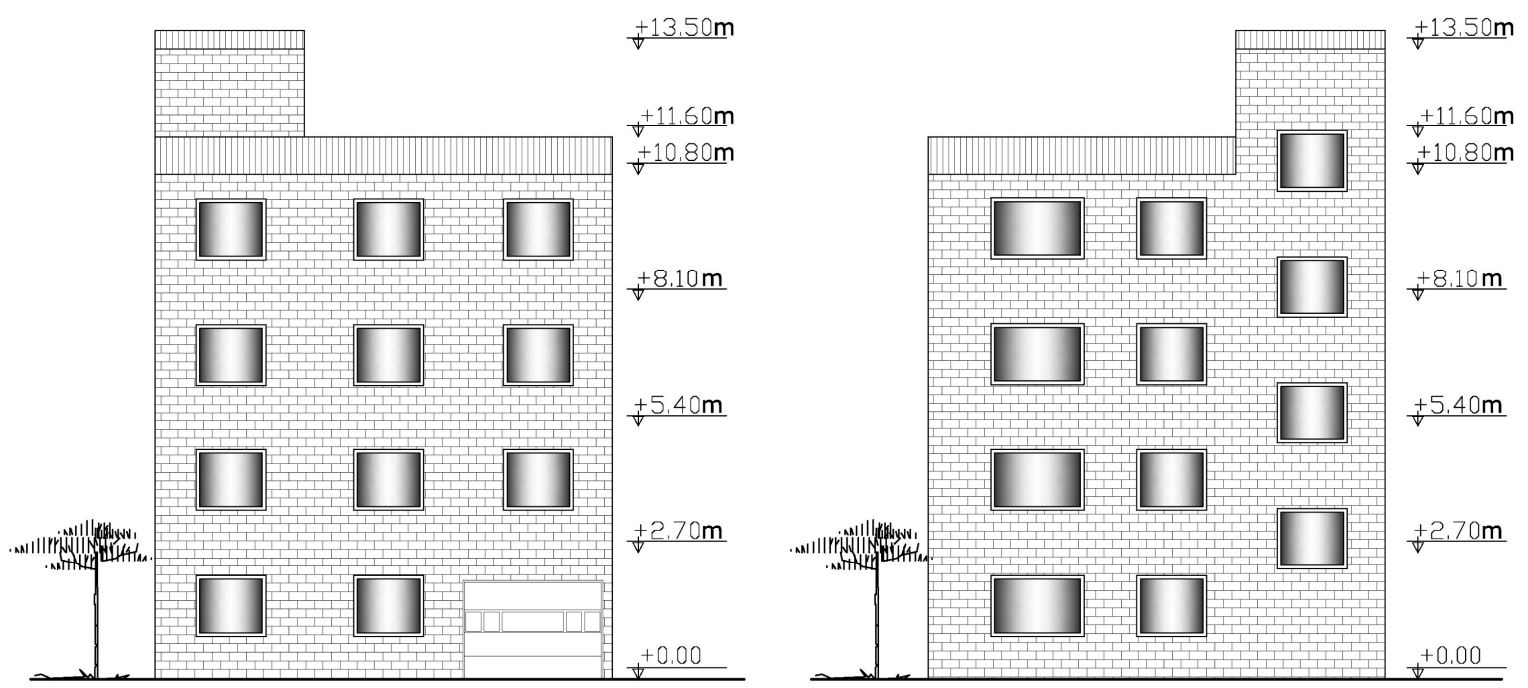

Figure 12. South and north elevations.

\section{Results and Discussion}

Simulations were carried out on the basis of thermal discomfort in London and results are shown in Figure 13. It seems that the SF system gives the lowest discomfort hours for the current climate but does not remain the same in future weather conditions. BB and SIP show very similar performance from 2020 and with up to a maximum $115 \mathrm{~h}$ advantage compared to ICF, TF and SF. However, BB, with the highest level of thermal mass, does not deliver the lowest discomfort hours in all time slices compared to the other systems. 


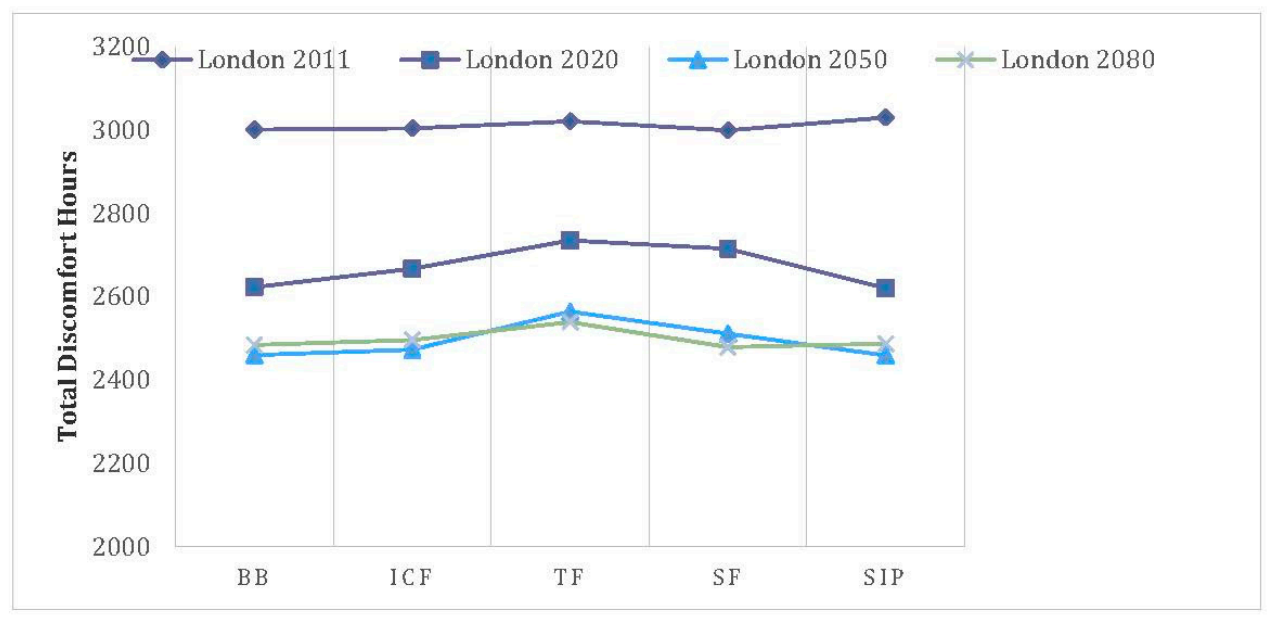

Figure 13. Total discomfort hours per block in London.

Climate change and temperature increase would certainly increase overheating risk, but on the other hand it would cause reduction in cooling loads. This study evaluates the behavior of the systems on the basis of overall comfort hours and Figure 13 shows that a reduction is expected. This paper does not address the practical issues relating exclusively to application of Predicted Mean Vote and Predicted Percent Dissatisfied (PMV-PPD). However, as shown in Figure 9, ASHRAE 2004 standard provides a relaxed thermal comfort zone for users of the standard, which sets aside certain local discomfort and personal factors that must be considered when using the other approaches in the standard. These other approaches, the Graphical Method and the Computer Model Method (predicted mean vote/predicted percent dissatisfied), are associated with ISO 7730 [20]. Therefore, for further clarification of each system's performance, further analysis on Figure 14 shows the performance of each system on the basis of PMV ( -3 very cold, -2 cool, -1 slightly cool, 0 neutral, +1 slightly warm, +2 warm +3 hot) in 2011 and 2080. (See Appendix A for an example of PMV/PPD inputs and outputs in one condition on the basis of clothing level $(\mathrm{Clo})$, air temperature $\left({ }^{\circ} \mathrm{C}\right)$, mean radiant temperature $\left({ }^{\circ} \mathrm{C}\right)$, air speed $(\mathrm{m} / \mathrm{s})$, relative humidity $(\%)$ and activity (MET)).

Figure 14 clarifies that there is a significant shift toward less overcooling in overall performance of the construction systems from 2011 to 2080 in terms of PMV, as the graph shows monthly average of PMV; it can be seen that inside the case is mostly facing overcooling (less than zero) than overheating (above zero) and there is a slight difference between each system.

In order to see how much energy is then required to remove discomfort hours, a fan coil unit is used for cooling and heating loads. Heating set point is considered at $18^{\circ} \mathrm{C}$ and cooling set point is considered at $28^{\circ} \mathrm{C}$. The coefficient of performance (COP) of the system is 1.6. Figure 15 shows the overall energy required to remove discomfort hours inside the model.

As observed, a high level of thermal mass does not necessarily deliver higher thermal comfort levels in all cases and it seems that the impact and benefits of thermal mass may have been overestimated in some literatures-although some advantages do undoubtedly exist in some cases.

Furthermore, the assessment of the systems on the basis of thermal comfort and energy consumption did not deliver entirely similar qualitative results. This is due to the fact that the assumption in this study was on the basis that any temperature out of the comfort zone is considered as discomfort and the difference between the systems in discomfort zone is not shown. For example $29^{\circ} \mathrm{C}$ and $30^{\circ} \mathrm{C}$ are both considered as discomfort hours but clearly more energy is required to reduce higher temperatures to the comfort zone. This could be highlighted when an SIP system is applied to the model and consumed maximum energy compared to the other systems, which is not noticeable in Figure 13. 


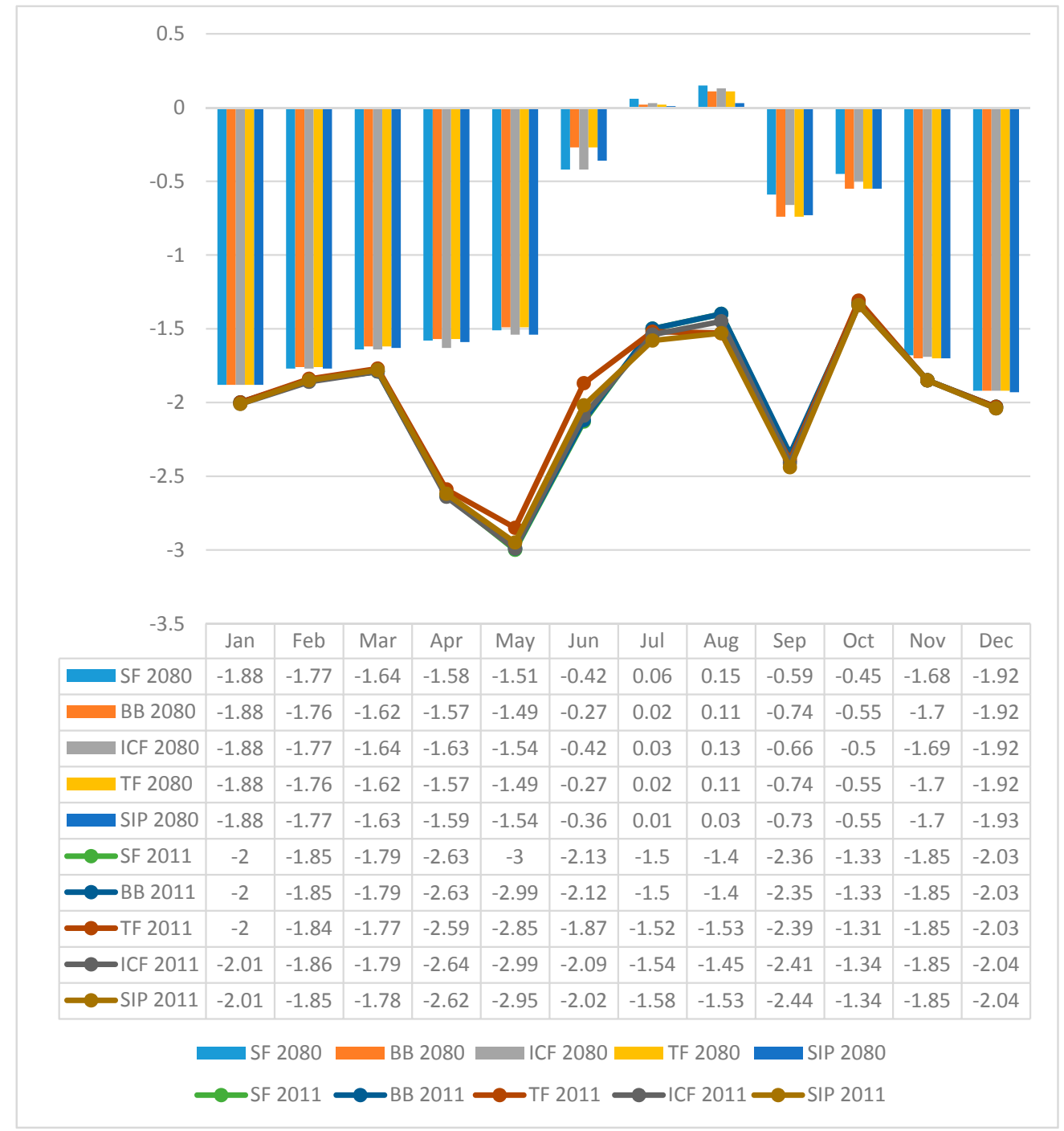

Figure 14. Monthly Predicted Mean Vote (PMV) average of each system in 2011 and 2080.

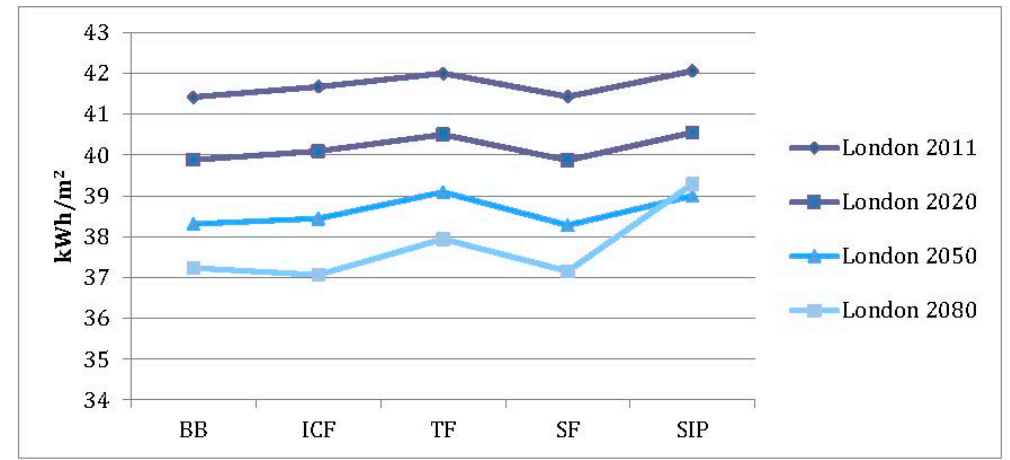

Figure 15. Overall energy consumption $(\mathrm{kWh} / \mathrm{m} 2)$ required removing discomfort hours.

Furthermore, the lowest performance from TF could also be due to its lowest decrement factor. Also the thickness of the systems does not seem to have any impact on their behavior in the simulations. The other factors such as material's reflectivity, transmissivity, emissivity and absorptivity could also have impact, which are referred for further studies. 


\section{Conclusions}

Dwellings being built today have at least several decades' operational lifetimes, making the impact of climate change an important design concern. The results presented in this study indicate that dwellings adapted for warmer temperatures using lightweight or heavyweight constructions are likely to provide higher levels of indoor comfort and lower energy consumption. This study evaluated the performance of heavyweight and lightweight construction systems in a changing climate and has quantified the performance of the wall types on the basis of thermal comfort and energy consumption. Specific conclusions can be categorized as below:

- A high level of thermal mass shows minor advantages in most cases for a typical flat model. This result is comparable to the Three Regions Climate Change Group (TRCCG) studies, which undertook similar research for 1960s houses and flats in London, and the east and southeast of England. They found that ventilation use, solar control, cooler floors, etc., were the most effective strategies to improve comfort in the UK housing [29].

- Although climate change will cause more demand for cooling loads and increase overheating hours in the UK, the impact on heating loads should not be neglected and overall energy consumption is subject to decrease when high performance systems are used in an airtight model. Heating load reduction is considerably higher than cooling load increase and therefore climate change would cause less overall energy consumption. This is also comparable to the results found from Collins et al. in a study on the entire UK housing stock in London, Manchester, Cardiff and Edinburgh [10].

- Although decrement factor and admittance factor do not necessarily characterize the behavior of the construction systems, it seems that a low level of decrement factor (TF) demonstrates maximum discomfort hours most of the time.

Conflicts of Interest: Author declares no conflicts of interest.

\section{Appendix A}

Designbuilder Screenshot, PMV\&PPD calculation inputs, a sample:

\begin{tabular}{|c|c|c|}
\hline $\begin{array}{l}\text { Thermal Comfort Calculator Data } \\
\text { Input }\end{array}$ & & \\
\hline Input & & $\approx$ \\
\hline Clothing (Clo) & 1.000 & \\
\hline Air temperature $\left({ }^{\circ} \mathrm{C}\right)$ & 22 & \\
\hline Mean radiant temperature $\left({ }^{\circ} \mathrm{C}\right)$ & 22.000 & \\
\hline Air speed (m/s) & 0.137 & \\
\hline Relative humidity (\%) & 45.000 & \\
\hline Activity method & 1-MET & 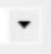 \\
\hline Activity (MET) & 1.000 & \\
\hline Output & & $\approx$ \\
\hline Operative temperature $\left({ }^{\circ} \mathrm{C}\right)$ & 22.00 & \\
\hline PMV & -0.46 & \\
\hline PPD (\%) & 9.47 & \\
\hline
\end{tabular}

Figure A1. PMV\&PPD calculation sample from DesignBuilder. 


\section{References}

1. Department for Communities and Local Government. Homes for Future: More Affordable, More Sustaianble; DCLG: London, UK, 2007.

2. Athienitis, A.K.; Santamouris, K. Thermal Analysis and Design of Passive Solar Buildings; James \& James Ltd.: London, UK, 2005.

3. Li, X.W.; Malkawi, A. Multi-objective optimization for thermal mass model predictive control in small and medium size commercial buildings under summer weather conditions. Energy 2016, 112, 1194-1206. [CrossRef]

4. Li, W.; Xu, P.; Wang, H.; Lu, X. A new method for calculating the thermal effects of irregular internal mass in buildings under demand response. Energy Build. 2016, 112, 761-772. [CrossRef]

5. Dunster, B. UK Housing and Climate Change: Heavyweight vs. Lightweight construction. In RIBA; Ove Arup \& Partners Ltd.: London, UK, 2005; Available online: http://www.architecture.com/Files/ RIBAProfessionalServices/Practice/UKHousingandclimatechange.pdf (accessed on 8 August 2016).

6. Orme, M.; Palmer, J.; Irving, S. Control of overheating in well-insulated housing. In Building Sustainability: Value and Profit; Building Services Research and Information Association: Bracknell, UK, 2003; Available online: http:/ / www.cibse.org/pdfs/7borme.pdf (accessed on 8 July 2016).

7. Building Research ESTABLISHMENT (BRE). The Passivhaus Standard. Available online: http://www. passivhaus.org.uk/standard (accessed on 8 July 2016).

8. De Wilde, P. The implications of a changing climate for buildings. Build. Environ. 2012, 55, 1-7. [CrossRef]

9. Hulme, M.; Jenkins, G.; Lu, X.F.; Turnpenny, J.; Mitchell, T.; Jones, R.; Lowe, J.; Murphy, J.; Hassel, D.; Boorman, P.; et al. Climate Change Scenarios for the United Kingdom, The UKCIP Scientific Report; Tyndall Centre for Climatic Change Research, School of Environmental Engineering, University of East Anglia: Norwich, UK, 2002; Available online: http:/ / www.ukcip.org.uk/resources/publications (accessed on 8 January 2017).

10. Collins, L.; Natarajan, S.; Levermore, G. Climate change and future energy consumption in UK housing stock. Build. Serv. Eng.Res. Technol. 2010, 31, 80-86. [CrossRef]

11. DCLG. English Housing Survey: Housing Stock Report; Department for Communities and Local Government: London, UK, 2008.

12. Childs, K.W.; Courville, G.E.; Bales, E.A. Thermal Mass Assessment: An Explanation of the Mechanisms by Which Building Mass Influences Heating and Cooling Energy Requirements; Department of Energy: Oak Ridge, TN, USA, 1983.

13. Orme, M.; Palmer, J. Control of Overheating in Future Housing_Design Guidance for Low Energy Strategies; Faber Maunsell: Lodon, UK, 2003.

14. Kosny, J.; Desjarlais, A.; Christian, J. Dynamic thermal performanc of concrete and masonry walls. In Proceeidngs of the Thermal Performance of the Exterior Envelopes of Buildings, Clearwater, FL, USA, 6-10 December 1998.

15. Chartered Institution of Building Services Engineers. Gudie A: Environmental Design; CIBSE: Lodon, UK, 2006.

16. British Standards Institute. Thermal Performance of Buildings-Calculation of Energy Needs for Space Heating and Cooling Using Dynamic Methods_General Criteria and Validation Procedures; BSI: London, UK, 2007.

17. The Concrete Centre. Thermal Mass for Housing; The concrete Centre: Surrey, UK, 2006.

18. British Standards Institute. Building Components and Building Elements-Thermal Resistance and Thermal Transmittance-Calculation Method; BSI: London, UK, 2003.

19. Clarke, J. Energy Simulation in Building Design; Butterwork-Heinemann: Oxford, UK, 2001.

20. ASHRAE 55 INT 2-2015 Thermal Environment Conditions for Human Occupancy; American Society of Heating, Refrigerating and Air-conditioning Engineers organization: Atlanta, GA, USA, 2013.

21. Kalogirou, S.; Florides, G.; Tassou, S. Energy analysis of buildings employing thermal mass in Cyprus. Renew. Energy 2002, 27, 353-368. [CrossRef]

22. Brisken, W.R.; Reque, S.G. Heat load calculations by thermal response. ASHVE Trans. 1956, 62, 391-424.

23. Davies, M. Building Heat Transfer; John Wiley and Sons: Sussex, UK, 2004.

24. Chudley, R.; Greeno, R. Building Construction Handbook; Elsevier: Oxford, UK, 2008.

25. MacLaren, F.H.; Dennis, L.; Mourshed, M. Public opinions on alternative lower carbon wall construction techniques for UK housing. Habitat Int. 2012, 37, 163-169. [CrossRef] 
26. Bregulla, J.; Enjily, V. An Introduction to Building with Structural Insulated Panels (SIP); BRE Construction Division: London, UK, 2004.

27. Muphy, J.; Sexton, D.; Jenkins, G.; Boorman, P.; Booth, B.; Brown, K.; Clark, R.; Collins, M.; Harris, G.; Kendon, L.; et al. UK Climate Projections Science Report: Climate Change Projection, version 3; Marine Climate Change Impacts Partnership: Durham, UK, 2010; Available online: http:/ /ukclimateprojections.defra.gov. $\mathrm{uk}$ /images/stories/projections_pdfs/UKCP09_Projections_V2.pdf (accessed on 8 September 2016).

28. Chandel, S.S.; Sharma, V.; Marwah, B.M. Review of energy efficient features in vernacular architecture for improving indoor thermal comfort conditions. Renew. Sustain. Energy Rev. 2016, 65, 459-477. [CrossRef]

29. Three Regions Climate Change Group. Your Home in a Changing Climate: Retrofitting Exisiting Homes for Climate Change Impacts; Greater London Authority: London, UK, 2008.

(C) 2017 by the author; licensee MDPI, Basel, Switzerland. This article is an open access article distributed under the terms and conditions of the Creative Commons Attribution (CC-BY) license (http://creativecommons.org/licenses/by/4.0/). 